\title{
ABSORPTIVE CAPACITY IN ANALYTICS IMPLEMENTATIONS: A RESEARCH MODEL*
}

\author{
RODRIGO FERREIRA ${ }^{1}$ \\ (iD) https://orcid.org/0000-0002-1766-0094 \\ JOSIR S. GOMES \\ (iD) https://orcid.org/0000-0002-2721-1786 \\ ANA CARVALHO ${ }^{2}$ \\ (D) http://orcid.org/0000-0001-8859-9959
}

To cite this paper: Ferreira, R., Gomes, J. S., \& Carvalho, A. (2020). Absorptive capacity in analytics implementations: A research model. Revista de Administração Mackenzie, 21 (2), 1-26. doi:10.1590/ 1678-6971/eRAMR200036

Submission: Mar. 14, 2019. Acceptance: Aug. 23, 2019.

* This paper was financed by National Funds of the Portuguese Foundation for Science and Technology (FCT) within the project «UID/ECO/03182/2019.

1 Universidade do Grande Rio (Unigranrio), Rio de Janeiro, RJ, Brazil.

2 Universidade do Minho (UM), Braga, Portugal.

\section{(c) $\mathrm{BY}$




\section{ABSTRACT}

Purpose: Propose a research model that involves the conceptual relationships between the theoretical support of the absorptive capacity and analytics, emphasizing the way in which the tool contributes to the formation of absorptive capacity within the companies.

Originality/value: It was possible to delineate a model with the theoretical associations between absorptive capacity and analytics from the voices of experts and decision makers of Portuguese companies, contributing as a tool to guide strategies that help companies for a better understanding of how the absorption of knowledge occurs in analytics implementations to better target efforts at incremental value generation.

Design/methodology/approach: A qualitative study was carried out with the adoption of Grounded Theory as a research strategy. In this way, techniques and procedures of the method were followed that allowed the constant collection and analysis of the data, supported with the use of Atlas.ti software.

Findings: The main theoretical contribution is the proposition of a conceptual model that considers emerging categories, subcategories, properties, and dimensions, that qualify the conceptual alignment between absorptive capacity and analytics and explain the existence of the construct over implementation. As entrepreneurial contributions, the configuration of knowledge absorption according to two analytic use patterns is emphasized: as oriented towards solving specific problems and as a guideline of institutional planning.

\section{KEYWORDS}

Absorptive capacity. Analytics. Big Data Analytics. Value extraction. Grounded Theory. 


\section{INTRODUCTION}

A recent Bain \& Company ${ }^{3}$ survey inspired the research. The study interviewed executives from more than 400 companies worldwide, most of them with revenues over $\$ 1$ billion. The topic addressed was data, analytics capabilities, and business decision making speed and effectiveness. The results revealed that only $4 \%$ of companies were proficient at analytics; $56 \%$ did not have suitable data capture systems or did not collect useful data, and; $66 \%$ lacked the proper technology for data storage and access. These results showed that, although the phenomenon is not recent, many companies have not yet understood how analytics can generate business value.

Nonetheless, the opportunities associated with the tool in different contexts help decision-makers understand their actual meaning (Grossman, 2018). These opportunities are always followed by challenges. On the one hand, analytics brings compelling opportunities (Bayrak, 2015; Ittmann, 2015). On the other hand, many challenges are faced when applied to solve business problems (Gartner, 2015; Tan, Zhan, Ji, Ye, \& Chang, 2015). Understanding how experts and decision-makers deal with the acquisition, assimilation, transformation, and application of knowledge in the process of analytics implementation becomes a relevant aspect as it allows the prioritization of conceptual elements present in those implementations, although neglected in the literature (Gao, Yeoh, Wong, \& Scheepers, 2017; Grover Chiang, Liang, \& Zhang, 2018; Rodriguez \& Cunha, 2018).

Given these facts, our study is justified by the possibility of serving as a basis for the emergence of categories favorable to the development of new concepts, techniques, and processes that explain the phenomenon. Advances in the exploration and use of analytics knowledge, in most cases, have their origin in the experience and interaction of the internal teams involved.

This research intends to contribute to this problem and aims to present an in-depth study with companies in order to propose a conceptual model that emerged from the collected data, emphasizing how the tool contributes to the formation of absorptive capacity. The proposed framework focuses on existing concepts in the statements and dimensions of absorptive capacity exposed by Zahra and George (2002) and Lane, Koka, and Pathak (2006) to create incremental business value.

To achieve this, the Grounded Theory techniques and procedures (Strauss \& Corbin, 2008) are used to explain, according to the interpretation

Retrieved from: https://www.bain.com/insights/the-value-of-big-data. Accessed on: Jan. 29, 2019. 
of meanings from the participants' point of view, the process of knowledge absorption in analytics implementation in major companies with intensive use of the technologies associated with the tool.

\section{ABSORPTIVE CAPACITY IN ANALYTICS IMPLEMENTATION}

In this study, analytics is regarded as "the science of analysis" (Davenport, 2006, p. 3), which is often characterized by uncertain or variable requirements, and a high risk of implementation (Viaene \& Bunder, 2011). Davenport (2006) first used the term analytics in an article entitled "Competing on analytics", published by the Harvard Business Review. This article was followed by the book with the same title (Davenport \& Harris, 2007). The publication is widely known for creating awareness of analytics. The definition given by Davenport (2006, p. 3) contains a term to which most decision-makers already relate. However, a more elaborate definition was developed: "by analytics we mean the extensive use of data, statistical and quantitative analysis, explanatory and predictive models, and fact-based management to drive decisions and actions" (Davenport \& Harris, 2007, p. 7). Many authors link the term to big data and competitive advantage generation through better business understanding (Kabir \& Carayannis, 2013; Holsapple, Lee-Post, \& Pakath, 2014; Gandomi \& Haider, 2015; Guszcza, 2015; Tan et al., 2015).

Research shows that the use of analytics assists in the decision-making process, having an influence over behavior, restricting the occurrence of cognitive biases (Guszcza, 2015), and, while Chen, Chiang, and Storey (2012, p. 1166) suggest that analytics and related technologies can help an organization to "better understand its business and markets", LaValle, Lesser, Shockley, Hopkins, and Kruschwitz (2011, p. 22) report that "top performers [...] make decisions based on rigorous analysis at more than double the rate of lower performers".

In complex private-sector environments, decision-makers are dealing not only with large volumes of data, but also with other more complex issues (Ittmann, 2015). By implementing analytics initiatives across organizations, decision-makers can integrate different data sources, forecast trends, improve performance, analyze key performance indicators, identify business opportunities, and make better, more informed decisions (Bayrak, 2015; Ittmann, 2015). 
The idea of having more or better-analyzed data helps decision-makers to understand current performance, and therefore, make decisions that improve the effectiveness or efficiency of the organization. A more resultsoriented view suggests that analytics should impact on the company's productivity, agility, innovation and reputation (Holsapple et al., 2014).

By relating analytics to the absorptive capacity construct, Grover et al. (2018) summarize the underlying theoretical logic to the analytics value creation. For the authors, the absorptive capacity logic indicates that the value of analytics occurs when an effective data integration to create innovation exists. They also explain this logic, as presented in Figure 2.1.

\section{(Figure 2.1) \\ THEORETICAL VALUE CREATION LOGIC}

\begin{tabular}{|c|c|}
\hline Logic & Explanation \\
\hline $\begin{array}{l}\text { Absorptive } \\
\text { capacity }\end{array}$ & $\begin{array}{l}\text { Value is based on the ability to identify valuable external knowledge, to assimilate } \\
\text { or transform it into the company's knowledge base and apply it through innovative } \\
\text { and competitive actions. }\end{array}$ \\
\hline
\end{tabular}

Source: Grover et al. (2018).

Other authors indicate absorptive capacity as a prerequisite (Kabir \& Carayannis, 2013) or facilitation resource for analytics (Wang, Kung, \& Byrd, 2015; Rodriguez \& Cunha, 2018), given its ability to deliver real-time critical information, and thus offering highlights for the acquisition, assimilation, transformation and application of such information and knowledge for commercial purposes (Rodriguez \& Cunha, 2018). However, despite a critical mass of research based on absorptive capacity, it seems that there has been no assessment of the role of this construct in the analytics context (Gao et al., 2017; Rodriguez \& Cunha, 2018; Grover et al., 2018).

Considered as the ability to identify, assimilate, and exploit knowledge (Cohen \& Levinthal, 1989), some authors have dedicated themselves to offering critical contributions since the introduction of the concept of absorptive capacity (e.g., Kim, 1998; Lane \& Lubatkin, 1998; Van den Bosch, Volberda, \& Boer, 1999; Van den Bosch \& Volberda, 2003; Zahra \& George, 2002; Liao, Welsch, \& Stoica, 2003; Matusik \& Heeley, 2005; Jansen, Van Den Bosch, \& Volberda, 2005; Lane et al., 2006; Todorova \& Durisin, 2007), demonstrating that the concept shows sufficient flexibility to be applied to different units of analysis and in a variety of research fields. 
For our study, the determinants of absorptive capacity proposed by Zahra and George (2002) and the concepts introduced by Lane et al. (2006) were taken into consideration. Figure 2.2 shows these antecedents and concepts.

\section{(Figure 2.2)}

\section{THE THEORETICAL MODEL FOLLOWED IN THE STUDY}

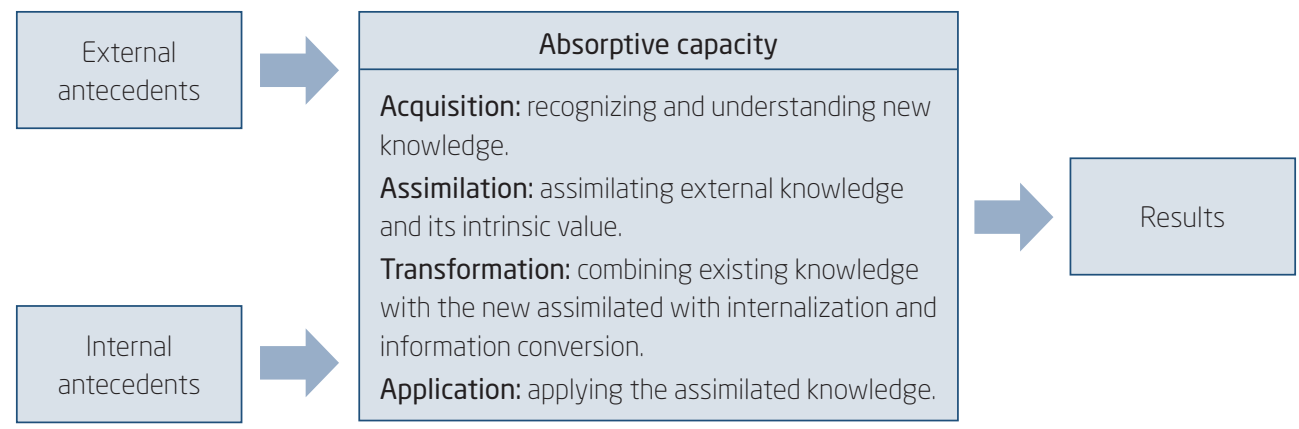

Source: Adapted from Zahra and George (2002, p. 192) and Lane et al. (2006, p. 856).

\section{METHODOLOGY}

The study was conducted in eight companies located in Portugal. The Straussian current techniques and procedures of the Grounded Theory method (Strauss \& Corbin, 2008) were used. The data were analyzed from the perspective of the subjects involved, underlining the peculiarities associated with the phenomenon through a subjective reality (Strauss \& Corbin, 2008). Thus, it relied on the real possibility of better clarifying the existing concepts in the context of analytics, explored from the absorptive capacity perspective.

The Grounded Theory method was chosen for two main reasons. Firstly, and emphasizing a learning method that emerges from the data, for seeking a balance between the theory that supports the study and the rationale for research derived from the data (Strauss \& Corbin, 2008). Secondly, in lies with one of the method's assumptions, in order to obtain useful results, the complexities of the organizational circumstances must be incorporated into the understanding of the phenomenon, which occupies or should occupy relative evidence within the organizational context, being a relevant framework to be comprehended.

The case selection was made by theoretical sampling (Glaser \& Strauss, 1967), not random. Thus, the selection aimed to ensure that most of the 
research objective was addressed, in other words, companies with analytics implementation experience. Consequently, the selection followed the criterion sampling strategy (Miles \& Huberman, 1990), whose logic is to identify cases that meet some previously defined importance criteria to ensure the quality of the collected data (Petrini \& Pozzebon, 2009). The focus on companies from various sectors and different locations throughout the country took into consideration two primary issues. In the first place, it was fundamental that the companies obtained business insights through a highly variable data set (Wang, 2015). Therefore, specialists or decisionmakers from the technical areas of development and implementation of analytics were necessary to ensure more considerable data variability.

In the second place, it was found that the introduction of companies that adequately represented such variations would require larger samples, located in different districts throughout the country, given the economic, social and cultural contrasts which characterized Portugal regions. Therefore, the regional variable was not restricted: data collection involved a reasonable complexity since it required the contribution of companies with practical cases of analytics implementations, and, above all, that most were already experimenting with the results as references.

Once the companies were selected, primary data were the information obtained from individuals who would better provide relevant information, i.e., experts or decision-makers from the information technology (IT) or business areas involved in analytics implementations. As a prerequisite, all participants should have had experience managing analytics initiatives or business areas that had participated in the implementation stages and were supported by analytics results.

Data were collected from December 2018 to March 2019 through in-depth interviews (McCracken, 1988) with open-ended questions (Foddy, 1993; Seidman, 2006). As a result, a total of eight individuals were interviewed (four respondents participated with additional, more profound questions), making a total of four hours of interview material, with an average of 30 minutes per subject.

In order to achieve success, it was beforehand considered for the first phase the possibility that some implementations were outlined for strategic issues, specifically on attracting new customers, products, or businesses. By having such characteristics, it can make it more challenging to identify and participate in companies or individuals who may reveal conceptual and managerial issues of high academic impact. In addition, analytics is still a relatively confusing topic within the organizational environment, as shown 
by the associations made by the market, such as data science, machine learning, business intelligence, and big data (Russom, 2011); as a result, some companies consider they do have analytics initiatives, but, in reality, this is limited to the capabilities of big data and/or business intelligence. Frequently, this fact is only discovered when the researcher is immersed in the data. For these reasons, the research targeted eight individuals who have proven experience through lato and stricto sensu postgraduate courses, and also for developing and/or having developed analytics projects, which ensured greater chances of emerging concepts and characteristics that originated data variability and guaranteed theory enrichment.

The second phase of the interviews sought to understand better the relationships between analytics implementations and the relevant elements revealed in the initial interviews, such as conditions of the functional areas involved, strategies performed throughout the process and potential for value generation with the phenomenon. Thus, four respondents identified as having multidisciplinary knowledge in the companies participated in answering additional questions. Figure 3.1 presents the profile of the research participants.

(Figure 3.1)

PARTICIPANTS PROFILE

\begin{tabular}{lllllll}
\hline Description & Profile & Area & Interview & $\begin{array}{c}\text { Country } \\
\text { region }\end{array}$ & Duration & $\begin{array}{c}\text { Additional } \\
\text { questions }\end{array}$ \\
\hline Interviewee 1 & Specialist & Business & Face-to-face & North & 00:36:51 & Yes \\
\hline Interviewee 2 & Manager & Technology & Face-to-face & North & 00:16:00 & \\
\hline Interviewee 3 & Specialist & Technology & Face-to-face & North & 00:43:28 & Yes \\
\hline Interviewee 4 & Manager & Business & Skype & North & 00:29:57 & Yes \\
\hline Interviewee 5 & Specialist & Business & Telephone & North & $00: 36: 52$ & Yes \\
\hline Interviewee 6 & Manager & Business & Face-to-face & Central & $00: 20: 04$ & \\
\hline Interviewee 7 & Specialist & Technology & Face-to-face & Central & $00: 27: 15$ & \\
\hline Interviewee 8 & Manager & Business & Face-to-face & North & $00: 30: 00$ & \\
\hline
\end{tabular}

Source: Elaborated by the authors.

The coding process was of three types: open, axial, and selective (Strauss, 1987; Strauss \& Corbin, 2008, p. 143). Open coding consisted of an analytical process whereby concepts were identified and their properties discovered 
within the data (Strauss \& Corbin, 2008). This phase involved the analysis of data observation in each paragraph and line of interview transcripts (Parker \& Roffey, 1996). Axial coding, in turn, was concerned with the development of categories beyond the properties and dimensions, which were systematically developed and associated with subcategories (Strauss \& Corbin, 2008, p. 143). The focus was to specify a category in terms of the conditions of its origin, the context of insertion, the strategies by which it was treated, and the consequences of those strategies (Jones \& Noble, 2007). Finally, the selective coding, aimed to integrate the various categories to "form a larger theoretical scheme" (Strauss \& Corbin, 1998, p. 143), occurred after the main categories were finally integrated to form such a scheme, assuming the form of theory (Strauss \& Corbin, 2008), correlating the principal codes derived from previous codifications (Parker \& Roffey, 1996).

Once theoretical saturation is reached, the process of relating categories, their properties, and interrelationships took place, generating a conceptual model with the investigation's main ideas and facts (Petrini \& Pozzebon, 2009). Regarding the criteria of internal validity, external reliability, and validity, respectively, it should be considered that:

- Reality is a social construction, based on the participants' perception: reliability is guaranteed by the consistency between the research results and the empirical data collected in the field.

- Human subjectivity is not governed by norms that promote equal results, nor should they: consistency between the search results and the empirical data collected in the field ensures reliability.

- External validity is explained by means of the general theory revealed through variations in the different discovered conditions (Strauss \& Corbin, 1998).

Figure 3.2 summarizes the Grounded Theory adopted steps and procedures.

\section{(Figure 3.2)}

GROUNDED THEORY STEPS AND PROCEDURES FOLLOWED IN THIS STUDY

\begin{tabular}{ll}
\hline \multicolumn{1}{c}{ Step description } & \multicolumn{1}{c}{ Activity } \\
\hline 1. Define and revisit theoretical support & Research question definition \\
\hline 2. Case selection & Theoretical sampling \\
\hline
\end{tabular}




\section{(Figure 3.2 (conclusion))}

GROUNDED THEORY STEPS AND PROCEDURES FOLLOWED IN THIS STUDY

\begin{tabular}{ll}
\hline \multicolumn{1}{c}{ Step description } & \multicolumn{1}{c}{ Activity } \\
\hline 3. Perform field research & Data collection through constant comparisons \\
\hline 4. Qualitative analysis software employment & Creation and use of analysis support elements \\
\hline 5. Data analysis & Application of open, axial and selective coding \\
\hline 6. New cases selection & Theoretical sampling \\
\hline 7. Establish theoretical saturation & $\begin{array}{l}\text { Elimination of marginal gains from the explanatory } \\
\text { power of the model }\end{array}$ \\
\hline 8. Revisit theory & Comparison of the model with theoretical support \\
\hline 9. Theoretical model demonstration & Demonstration of the emerging model \\
\hline
\end{tabular}

Source: Elaborated by the authors.

\section{RESULTS AND ANALYSIS}

The interviews were transcribed and the data were analyzed with the support of the recent 8.3.20 version of qualitative analysis software Atlas.ti (Friese, 2017), consistent with the techniques and procedures of the Straussian current method of the Grounded Theory (Strauss \& Corbin, 2008). The software helped the researcher to obtain greater efficiency in data collection and analysis, using the following artifacts: hermeneutic unit, primary documents, citations, codes, memorandums, and networks (Costa \& Itelvino, 2018).

The analysis phase began immediately after the first interview. As the analysis progressed, the interviews became more structured, with concentrated questions created around the emerging categories. The analysis made using the absorptive capacity as theoretical support considered the five categories contained in the Zahra \& George (2002, p. 192) and Lane et al. (2006, p. 856) models to explain the phenomenon: 1 . antecedents; 2 . knowledge acquisition; 3. knowledge assimilation; 4. knowledge transformation; and 5. knowledge application. In addition to these categories, the data interpretation found evidence of their respective subcategories and properties.

Regarding the antecedents of absorptive capacity in analytics, strategic partnerships and complementary individual knowledge were identified. 
Defined as "voluntary arrangements between firms involving exchange, sharing, or co-development of products, technologies or services" (Gulati, 1998, p. 293), strategic partnerships are revealed as one of the starting points for the research model. They are considered tools for the acquisition and assimilation and further transformation and exploitation of knowledge (Zahra \& George, 2002), and have been used as a means of gaining access to valuable partner resources (Sáez, Arribas, \& García, 2002), especially concerning the development of technologies associated with analytics.

Additionally, complementary individual knowledge (Zahra \& George, 2002) was also evidenced in the data as one of the antecedents of the absorptive capacity with the ability to deal with the dynamism of the environment (Volberda \& Van Bruggen, 1997) involving analytics. These antecedents, by reacting to activation triggers, force the company to respond to internal and external stimuli (Walsh \& Ugson, 1991) and to amplify the absorptive capacity, since they increase the possibility of identifying knowledge crucial to operations (Zahra \& George, 2002) and allow its reach (Cohen \& Levinthal, 1990), emphasizing the idea that absorptive capacity is triggered through networks built from individual resources, which increase according to the interactions made by individuals which possess different knowledge, thus, generating new innovative networks (Nelson \& Winter, 1982). Then, it became clear that the identified antecedents are fundamental conditions for companies to be able to identify and evaluate analytics knowledge that goes beyond their borders (Cohen \& Levinthal, 1990), as well as the complementary individual knowledge (Zahra \& George, 2002).

Regarding the next category, knowledge acquisition, it was inferred from data analysis that the adoption of analytics in the environment is encouraged by two main properties: 1. identification of internal knowledge structures, and 2. identification of external knowledge structures. The analysis showed the identification of internal and external knowledge structures properties, which serve as triggers (Walsh \& Ugson, 1991) to activate new opportunities and detected challenges. Those structures are considered internal when stimuli are individually originated in the internal environment (Cohen \& Levinthal, 1990) or external, when originated in the external environment (Zahra \& George, 2002). In the analyzed data, internal knowledge structures begin to exist from the internal skills and from the propensity to discover the potential that analytics can offer to the business. These results are important for team leaders and decision-makers. Practically, leaders need to keep a balance between expecting these skills to be present in all team members and ensuring that these attributes are in fact recognized by the team (Nemanich, Keller, Vera, \& Chin, 2010). 
Therefore, when there is low access to external knowledge and low propensity for internal knowledge structures, the team's mental model tends to remain unfavorable to the prospect of following the progress of analytics related technologies, which shows little or no opportunity for identification of these structures and, consequently, the non-activation of knowledge acquisition. On the other hand, if there is high or moderate access to external knowledge, as well as a high or moderate propensity for internal knowledge structures, the team's mental model tends to present itself favorably to emerging technologies. Thus, it provides the positive dimensional variation and defines the existence of an opportunity to knowledge acquisition about concepts and technologies related to analytics.

The knowledge acquisition category evidenced in the data presupposes employees' propensities concerning access to continuous learning, regardless of whether or not sponsored by the company itself. In other words, the individual perceives the importance of analytics as an instrument of business value creation, and, as a result, turns to universities and educational institutions to gain knowledge about these technologies. In addition, the level of knowledge acquisition can also be explained by the satisfactory access to technologies related to the phenomenon, based on data from the partnerships practiced between the companies and the leading country's universities, even through educational and technological reciprocity agreements.

Therefore, the variation between low access or low propensity for knowledge structures results in staff stagnation and a low opportunity for knowledge acquisition regarding usual analytics technologies. This stagnation can lead to a vicious cycle in the company, where business value creation opportunities are overlooked by the inapplicability of technologies that could solve problems through analytics (Chen et al., 2012).

The next category is the way knowledge assimilation is adopted by companies to use analytics. The data show differences in how companies appropriated existing knowledge structures, bringing implications to managing the implementation process. So, emphasis was made on trying to understand how knowledge appropriation around analytics is handled by companies and how it affects implementation. Basically, two types of variations were identified: how teams that deal directly with analytics are positioned within companies; and how support is provided for the integration of the teams involved with the implementations. Thus, the assimilation category was defined as the company's ability to process new information or newly acquired knowledge (Szulanski, 1996; Zahra \& George, 2002), being characterized by two properties: knowledge structures appropriation and ideas, and knowledge appropriation. 
According to the data, the way that teams that deal directly with analytics, and include data scientists, are positioned within the organizational structure indicates the transversality of these teams. Thus, the more traversal, the higher the chances of IT and business teams' integration. Evidence shows that, in some cases, data scientist teams are labeled separately, distinctively from IT and business teams. While these teams usually have well-defined roles, teams of data scientists aim to reduce the uncertainty that companies have about a broader range of problems (Costa \& Santos, 2017), which, traditionally, are challenging to discover (Verma, 2017). Therefore, as data scientists are transversal across the structure, it appears to be creating a favorable environment for problem-solving through analytics.

The second property, appropriating ideas and knowledge, is characterized by supporting the integration of the teams involved with analytics implementations. In knowing the potential of the positive results that the use of analytics can bring, in addition to the traditional roles that IT and business teams play, companies realize the importance of knowledge complementarity (Zahra \& George, 2002) between these areas, so that the IT team helps business teams overcome any limitations with technology, and the business team can better realize that exchanging information about everyday issues can improve the way tasks are performed, for example. Moreover, from the study, it became clear that analytics implementations are dynamic. In many cases, professional data scientists face challenges: not knowing for sure if they will bring results in the end, because, even knowing the path to be followed, it is not always known what will be found that may prevent a successful implementation. Therefore, so that practical difficulties are minimally lessened, there is evidence that team engagement encouragement by decision-makers is critical (Nemanich et al., 2010).

The combination of these two properties defines the pattern of appropriation of ideas and knowledge structures by companies, characterized in the study by two patterns. The first one refers to the transversality level of the data scientists teams in the organizational structure. In this case, the dimension ranges from low to high and indicates the degree of access to the other teams involved, generating an environment of reciprocity in problem-solving through analytics. The second pattern is defined by the level of support for team integration, which ranges from low to high, whether or not it generates the premise of a reciprocal environment, working in an integrated manner, with analytics as the tool that can solve business-related problems (Bayrak, 2015; Ittmann, 2015).

The category knowledge transformation is related to the legitimacy placed by the receptor teams and the decision-makers to the analytics products. 
Evidence shows that the developed analytics product only begins to be effectively used by teams when the criteria used to verify whether it is appropriate to the context to which it claims to be part of is accepted. With high legitimacy, the product tends to be effectively operationalized by the teams. Otherwise, it appears that the desired results are not efficiently achieved. Therefore, the applicability of analytics results by members of the organization is intrinsically linked to the legitimacy attributed to them.

The legitimacy attributed by teams and decision-makers can be perceived by the efficiency in the communication with stakeholders. The team involved in the implementation of analytics must ensure that the ideas and results generated by analytics can solve business-related problems that arise from different areas of the company. This assurance is given through communication, which is characterized by the form of presentation to be made and the level of discussions to be stimulated. For this, the receiver client profile and the communication objectives must be considered. For example, if the client is the company's board, a more synthetic communication should be prepared. If the client belongs to the business team that will operate analytics itself, communication should be predominantly analytical, allowing the exchange of ideas and information between the implementation team and its client. The data demonstrate that effective communication induces legitimacy as to the applicability of analytics. For both profiles, visual and objectivity criteria should be prioritized.

The category knowledge application represents the degree of adherence of analytics results to the peculiarities of the environment, characterized by the cost-benefit ratio. These results often require significant adjustments to the organizational processes and assets, which can lead to unforeseen expenses or actions. Thus, a cost-benefit ratio analysis takes place and the results are operationalized when this relationship is satisfactory. It must be noted that part of the dimension knowledge application will not be put into effect and the absorptive capacity will not be fully developed and systematized if this relationship is not favorable and the analytics results are not operationalized by the company. However, the data show that the cost-benefit ratio also considers the gain in experience that the team will have after the implementation of analytics, from the accumulation of knowledge that their results can provide, allowing the internalization of learning and results improvements in future implementations.

Figure 4.1 summarizes the four categories and their properties. Next, the relationship between them in order to build the substantive theory is examined. It is essential to note that the theory is presented in a structured 
way; that is, each category has been appropriately defined and characterized
by its properties.

(Figure 4.1)

THE CONSTITUTIVE ELEMENTS OF THE EMERGENT SUBSTANTIVE THEORY

\begin{tabular}{|c|c|c|c|}
\hline Category & Subcategory & Properties & Dimensional variation \\
\hline \multirow[t]{4}{*}{ Acquisition } & \multirow[t]{2}{*}{ Pre analytics } & \multirow{2}{*}{$\begin{array}{l}\text { Identify internal and } \\
\text { external knowledge } \\
\text { structures }\end{array}$} & $\begin{array}{l}\text { Low stimulus: orthodox mental model for emerging } \\
\text { technologies. }\end{array}$ \\
\hline & & & $\begin{array}{l}\text { High stimulus: contemporary mental model for } \\
\text { emerging technologies. }\end{array}$ \\
\hline & \multirow[t]{2}{*}{ Post analytics } & \multirow[t]{2}{*}{$\begin{array}{l}\text { Encourage collective } \\
\text { insights }\end{array}$} & $\begin{array}{l}\text { Low incentive: regarding the generation of questions } \\
\text { to the results provided by analytics. }\end{array}$ \\
\hline & & & $\begin{array}{l}\text { High incentive: regarding the generation of questions } \\
\text { to the results provided by analytics. }\end{array}$ \\
\hline \multirow[t]{3}{*}{ Assimilation } & \multirow[t]{2}{*}{ Pre analytics } & \multirow{2}{*}{$\begin{array}{l}\text { Appropriate } \\
\text { knowledge } \\
\text { structures }\end{array}$} & $\begin{array}{l}\text { Low team transversality: teams of data scientists do } \\
\text { not position themselves across companies. }\end{array}$ \\
\hline & & & $\begin{array}{l}\text { High team transversality: teams of data scientists } \\
\text { position themselves across companies. }\end{array}$ \\
\hline & $\begin{array}{l}\text { Pre/post } \\
\text { analytics }\end{array}$ & $\begin{array}{l}\text { Appropriate ideas } \\
\text { and knowledge }\end{array}$ & $\begin{array}{l}\text { Low support for teams integration: which prevents from } \\
\text { bringing people together, helping them evolve in the } \\
\text { use of analytics-related technologies. }\end{array}$ \\
\hline
\end{tabular}

High support for teams integration: which provides for union between people, helping them evolve in the use of analytics-related technologies.

\begin{tabular}{|c|c|c|c|}
\hline \multirow[t]{8}{*}{ Transformation } & \multirow[t]{2}{*}{ Pre analytics } & \multirow[t]{2}{*}{$\begin{array}{l}\text { Create legitimacy } \\
\text { in problem-solving }\end{array}$} & $\begin{array}{l}\text { Low legitimacy: teams and decision-makers do not } \\
\text { perceive analytics to be helpful to business. }\end{array}$ \\
\hline & & & $\begin{array}{l}\text { High legitimacy: Teams and decision-makers perceive } \\
\text { analytics to be helpful to business. }\end{array}$ \\
\hline & \multirow[t]{6}{*}{ Post analytics } & \multirow[t]{6}{*}{$\begin{array}{l}\text { Develop analytical } \\
\text { maturity }\end{array}$} & $\begin{array}{l}\text { Non-insertion of analytics in the company's } \\
\text { institutional planning. }\end{array}$ \\
\hline & & & $\begin{array}{l}\text { Insertion of analytics in the company's institutional } \\
\text { planning. }\end{array}$ \\
\hline & & & Non-use of indicators. \\
\hline & & & Use of indicators. \\
\hline & & & No practical experience in previous implementations. \\
\hline & & & Practical experience in previous implementations. \\
\hline
\end{tabular}




\section{(Figure 4.1 (conclusion))}

THE CONSTITUTIVE ELEMENTS OF THE EMERGENT SUBSTANTIVE THEORY

\begin{tabular}{|c|c|c|c|}
\hline Category & Subcategory & Properties & Dimensional variation \\
\hline \multirow[t]{4}{*}{ Application } & \multirow[t]{2}{*}{ Pre analytics } & \multirow[t]{4}{*}{ Analytics results } & Weak input: for collective incentives generation. \\
\hline & & & Strong input: for collective incentives generation. \\
\hline & \multirow[t]{2}{*}{ Post analytics } & & Low efficiency in products, processes, and analytics. \\
\hline & & & High efficiency in products, processes, and analytics. \\
\hline
\end{tabular}

Source: Elaborated by the authors.

\subsection{The emerging conceptual model}

An important aspect of the Grounded Theory is the identification of a core category to which all others relate to. Throughout the analysis process, it was appreciated that knowledge absorption in analytics was not only associated with the way absorptive capacity occurs throughout analytics implementations ("pre analytics" subcategory, in Figure 4.1), but above all, with how the tool operationalization contributes to the formation of companies' absorptive capacity ("post analytics" subcategory, in Figure 4.1). Therefore, as data analysis progressed, it became clearer that the main category was the way in which companies conduct the concept of analytics in their environments. According to the data, the adoption of new perspectives can make a difference in generating business results and transforming the company to deal with the phenomenon from a value creation perspective.

In addition to the properties already distinguished, new properties are drawn from the analytics results, which were called "post analytics" subcategories, i.e., after the implementations, the company tends to receive inputs that lead to a series of internal discussions. These discussions tend to generate insights and a fresh new look about products, processes, and analytics itself. In this way, a new property, encourage collective insights, is evidenced in the data. At this point, the virtuous cycle of absorptive capacity in analytics begins, in which the company has the opportunity to obtain new business ideas and knowledge through collective alignments, sourced by the analytics results. The collective insights are driven by analytics results, in which the involved areas receive inputs that can serve to improve processes and products. At this time, it seems that the collective insights provoke adaptations and improvements with the incorporation of new data or data sources to be considered in the analytics outcome, improving its results even further. Hence the virtuous cycle. 
Given these collective insights, the ideas and knowledge brought about by analytics results may, or may not, be assimilated by the teams involved. Once again, proper support from the decision-makers to teams' integration is crucial at this time, being identified as the property that sustains the problem-solving dynamics and provides the necessary breathing space for teams to adjust the reality to the new ideas and knowledge arising from analytics.

Therefore, the main issue observed in the data on the occurrence of absorptive capacity in analytics implementations is that technology helps in institutional planning elaboration, the main category identified being "absorptive capacity in analytics". Thus, it became evident that companies choose the attribute of analytical maturity as the path that provides for better results in innovation and efficiency of products, processes, and analytics.

This analytical maturity is characterized as the stage at which the company has reached full development concerning analytics, so its results are definitive to the strategies the company will follow in the next period. Thus, stimulated by the economic and financial situation, it is defined in institutional planning that the implementation of analytics for the marketing area should be concerned with three basic processes: customer acquisition, management, and exit, as stated by one of the participants. Therefore, teams' efforts will be directed towards raising answers to clarify flaws or solve problems related to these three major action blocks. From there, the teams undertake analytics implementation that guarantees incremental value generation within these processes. This stage is rich in generating collective insights: once it is jointly found that the main issue to be addressed is, for example, customer acquisition, all analytics work will be driven in that direction, generating new collective insights into how teams will solve the identified problem, resulting in new ideas and information exchange.

The other properties, analytics guiding planning, use of indicators, and practical experience, define analytical maturity. As a result of the experience in previous implementations, especially in those in which there has been an effective generation of business insights, companies will set up analytics indicators. For example, if the implementation was made with the intention of solving customer acquisition problems, then the number of new customers can be established as a daily indicator. From these experiences, it seems that there is greater visibility of the importance of analytics by internal teams, so that it begins to provide drivers for institutional planning: the company begins to use analytics results to guide its business planning, reaching analytical maturity. 
At this point, it is noteworthy that, problems being identified and analytics results being continuously developed in a multidisciplinary manner, provide a legitimacy capable of strengthening teams, intensifying active cooperation mechanisms and creating a knowledge base with opportunities for effective improvements. This knowledge base enables analytics teams to solve future problems more easily by the accumulated experience. However, with this accumulated experience and legitimacy gained, business teams naturally deploy new analytics implementations through new attributes defined in the new institutional planning. This recurrence tends to provide analytical maturity until companies begin to use analytics results to guide their institutional planning.

\section{(Figure 4.1.1) \\ PROPOSED THEORETICAL MODEL}

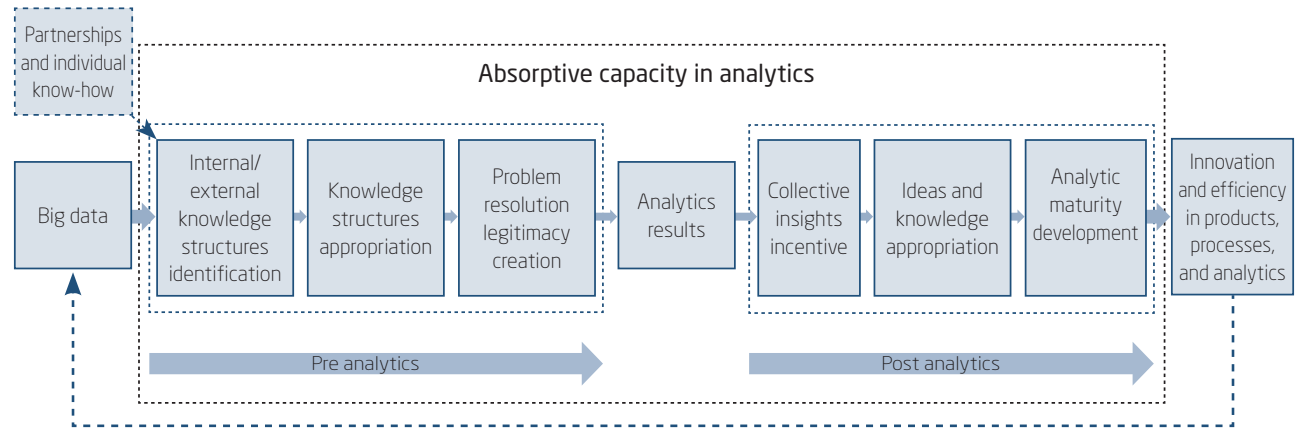

Source: Elaborated by the authors.

\section{CONCLUSIONS}

A research model that integrates absorption capacity and analytics has been developed. The analysis shows how absorptive capacity occurs in analytics implementations, as well as how this tool contributes to absorptive capacity formation. The results demonstrate that the construct is vital to understand the different patterns of knowledge appropriation resulting from the generation and appropriation of specific internal and external knowledge structures, as well as to the creation of legitimacy around the results provided by analytics.

Additionally, evidence shows how these results sponsor absorptive capacity building, given the need for alignment between the impacted teams, 
demanding efforts across the company. These alignments require appropriations, influenced by the support for integrations among teams that lead to innovation and organizational efficiency. These results provide implications for research and practice in the areas of absorptive capacity in analytics contexts.

The understanding of how the meaning around analytics is built within companies derives from how they are able to transform the tool results in a source of oxygen between the teams and institutional planning. This contributes to the understanding of the formation of two different patterns of appropriation of analytical knowledge in the analyzed companies: one oriented to solve specific problems and another one oriented to the definition of institutional planning. The first pattern develops absorptive capacity only throughout the implementations, while the second pattern also develops throughout the implementations, but contributing to the increase of the company's absorptive capacity. Thus, the main contribution of this study is the empirical demonstration of how analytics implementations are susceptible to the way knowledge is absorbed, leading companies to different technology appropriation patterns.

These results provide several direct implications for companies. Managers who want to derive gains from analytics in a well-connected organizational environment need to consider the experience that internal teams have with this technology. Experience facilitates the company's ability to identify, assimilate, transform, and apply valuable external knowledge in stable and dynamic environments. In addition, inter-organizational partnerships enhance a company's ability to leverage frameworks for analytics knowledge absorption efforts. However, it is necessary to create mechanisms for the knowledge appropriation generated by experience and partnerships, so that the results of the technology can be internally recognized and legitimated, being the trigger for the generation of collective insights, new appropriations, and analytical maturity as a way to absorb external knowledge valuable in fast-paced environments.

However, other contributions can be mentioned. By examining the process from a perspective that considers the interpretation of technology by experts and decision-makers, we can better understand how analytics has been appropriated and used in companies. This approach suggests a new paradigm for analyzing the technology implementation in contrast to descriptive or normative researches. The emerging model in the study allows us to explain the knowledge absorption in analytics before and after implementations, which has been omitted in the literature (Gao et al., 2017; 
Grover et al., 2018; Rodriguez \& Cunha, 2018). Additionally, legitimacy was identified as a critical factor, affecting analytics implementation and dissemination in the studied companies' environments. The findings indicate that the way teams legitimize technology outcomes influences their applicability. For managers, the understanding of the theoretical elements present in the research may be fundamental to define strategies that can help them remain competitive, minimizing threats from the external environment. Thus, the study becomes relevant as it provides practitioners with a practical view of how investments and efforts in analytics can be leveraged to generate value and profit from projects of this nature, facilitating the planning and actions to be taken by specific functional areas of intelligence, knowledge management, or related.

This empirical analysis intends to make theoretical generalizations: it is expected that the model explains how knowledge absorption in analytics occur in companies, as well as how certain events and situations are interpreted by individuals. The Grounded Theory method used is based on the idea that events and objects have no intrinsic meaning different from those that individuals attribute to them in the course of their social interactions. The understanding of analytics implementation requires sensitivity to the way participants interpret and create meaning around the investigated object. However, despite the specific conditions associated with this study, the results found may serve as guidelines for other companies. Nevertheless, further research in other countries is suggested to verify similar patterns with the intention of seeking greater variability of results.

The study emphasizes three main contributions: 1 . it offers a research synthesis on analytics implementation, broadening the scope for practice and research within the phenomenon; 2 . it proposes the adoption of practical alternative absorptive capacity-building practices that can minimize challenges inherent to the implementation of analytics; and 3. it shows the opportunities that may arise from repositioning companies' business models to develop analytical maturity as a means of transforming the status quo.

Taking into consideration the potential of these contributions, the following research suggestions arise: 1 . to comparatively study the challenges faced in analytics implementations by companies from various sectors and countries; 2 . to research the articulations that occurred between the actors involved, using other respondents, from different areas and organizational levels; 3 . to consider absorptive capacity in public organizations, whose idiosyncrasies may raise other relevant managerial, technical, and social issues. Fourth, to research incentive mechanisms that may optimize the use of analytics. 
After discussing the implications, the study's limitations are acknowledged. Firstly, a single informant for each participating company may generate a potential common method bias. The Grounded Theory method used is based on the idea that events and objects have no intrinsic meaning apart from those attributed to them by individuals in the course of social interactions. However, common method bias does not seem to threaten the validity of these results, given the use of qualitative approach techniques to inhibit too many positive statements, rather than revealing other idiosyncrasies suffered by the companies in the context of implementations in which the respondents participated. Although the single informant approach has been widely applied in empirical organizational research (Cycyota \& Harrison, 2006), it is limited to an individual's view of their organization and environment. The use of other agents to increase data variability is suggested.

Secondly, the research includes experts and decision-makers who can maximize overly positive statements about analytics implementations, especially those in which they are or were responsible for. Finally, the focus has been on private companies, which may cause some reduction by sector and other alternative explanations that could complement the concepts and relationships that emerged from the investigation. However, despite the conditions associated with this study, the results may not be fully applicable to other sectors. Future research should explore, for example, the public sector for better understanding of the value of the absorptive capacity construct in the analytics contexts.

\section{CAPACIDADE ABSORTIVA EM IMPLEMENTAÇÕES DE ANALYTICS: UM MODELO DE PESQUISA}

\section{RESUMO}

Objetivo: Apresentar um estudo em profundidade com empresas portuguesas a fim de propor um modelo conceitual que emergiu dos dados coletados, enfatizando o modo como a ferramenta contribui para a formação de capacidade absortiva.

Originalidade/valor: Foi possível delinear um modelo com as associações teóricas entre capacidade absortiva e analytics a partir das vozes de especialistas e tomadores de decisão de empresas portuguesas, contribuindo como instrumento para orientar estratégias que ajudem as empresas a compreender melhor como acontece a absorção do conhecimento em 
implementações de analytics para um direcionamento mais eficiente de esforços e consequente geração de valor incremental.

Design/metodologia/abordagem: Realizou-se um estudo de natureza qualitativa com a adoção da Grounded Theory como estratégia de pesquisa. Dessa forma, adotaram-se técnicas e procedimentos do método que permitiram a constante coleta e análise dos dados. Para tanto, utilizou-se o software Atlas.ti.

Resultados: A principal contribuição teórica é a proposição de um modelo conceitual que considere as categorias, subcategorias, propriedades e dimensões emergentes, que qualificam o alinhamento conceitual entre capacidade absortiva e analytics e explicam a existência do construto ao longo da implementação. Como contribuições empresariais, ressalta-se a configuração da absorção do conhecimento de acordo com dois padrões de uso do analytics: orientado à resolução de problemas específicos e como orientador do planejamento institucional.

\section{PALAVRAS-ChAVE}

Capacidade absortiva. Analytics. Big Data Analytics. Extração de valor. Grounded Theory.

\section{REFERENCES}

Bayrak, T. (2015). A review of business analytics: A business enabler or another passing fad. Procedia - Social and Behavioral Sciences, 195, 230-239.

Chen, H., Chiang, R. H. L., \& Storey, V. C. (2012). Business intelligence and analytics: From Big Data to Big Impact. Mis Quarterly, 36(4), 1165-1188.

Cohen, W. M., \& Levinthal, D. A. (1989). Innovation and learning: The two faces of R\&D. Economic Journal, 99(397), 569-596.

Cohen, W. M., \& Levinthal, D. A. (1990). Absorptive capacity: A new perspective on learning and innovation. Administrative Science Quarterly, 35(1), 128-152.

Costa, C., \& Santos, M. Y. (2017). The data scientist profile and its representativeness in the European e-Competence framework and the skills framework for the information age. International Journal of Information Management, 37(6), 726-734. 
Costa, P., \& Itelvino, L. (2018). Grounded Theory com utilização do software Atlas.ti: Um exemplo empírico de estudo sobre estratégia de ascensão do empreendedorismo inovador em negócios sociais. Iberoamerican Journal of Strategic Management, 17(3), 17-40.

Cycyota, C. S., \& Harrison, D. A. (2006). What (not) to expect when surveying executives: A meta-analysis of top manager response rates and techniques over time. Organizational Research Methods, 9(2), 133-160.

Davenport, T. H. (2006). Competing on analytics. Harvard Business Review, 84(1), 98-107.

Davenport, T. H., \& Harris, J. G. (2007). Competing on analytics: The new science of winning. Boston, MA: Harvard Business School Review Press.

Foddy, W. (1993). Constructing questions for interviews and questionnaires: Theory and practice in social research. New York: Cambridge University Press.

Friese, S. (2017). ATLAS.ti 8 Windows Quick Tour. Berlin: Atlas.ti scientific software development.

Gandomi, A., \& Haider, M. (2015). Big data concepts, methods and analytics. International Journal of Information Management, 35, 137-144.

Gao, S., Yeoh, W., Wong, S. F., \& Scheepers, R. (2017). A literature analysis of the use of absorptive capacity construct in IS research. International Journal of Information Management, 37(2), 36-42.

Gartner. (2015). Flipping to digital leadership: Insights from the 2015 CIO Agenda Report. Gartner.

Glaser, B., \& Strauss, A. (1967). The discovery of grounded theory: Strategies for qualitative research. New York: Aldine de Gruyter.

Grossman, R. L. (2018). A framework for evaluating the analytic maturity of an organization. International Journal of Information Management, 38(1), 45-51.

Grover, V., Chiang, R. H. L., Liang, T., \& Zhang, D. (2018). Creating strategic business value from Big Data Analytics: A research framework. Journal of Management Information Systems, 35(2), 388-423.

Gulati, R. (1998). Alliances and networks. Strategic Management Journal, 19, 293-317.

Guszcza, J. (2015). The last-mile problem. How data science and behavioral science can work together. Delloite.

Holsapple, C., Lee-Post, A., \& Pakath, R. (2014). A unified foundation for business analytics. Decision Support Sciences, 64, 130-141. 
Irving, S. (2006). Interviewing as qualitative research: A guide for researchers in education and the social sciences (3rd ed.). New York: Teachers College Press.

Ittmann, H. W. (2015). The impact of big data and business analytics on supply chain management. Journal of Transport and Supply Chain Management, 9(1), 1-9.

Jansen, J. J. P., Van Den Bosch, F. A. J., \& Volberda, H. W. (2005). Managing potential and realized absorptive capacity: How do organizational antecedents matter? Academy of Management Journal, 48(6), 999-1015.

Jones, R., \& Noble, G. (2007). Grounded theory and management research: A lack of integrity? Qualitative Research in Organizations and Management: An International Journal, 2(2), 84-103.

Kabir, N., \& Carayannis, E. (2013). Big data, tacit knowledge and organizational competitiveness. Journal of Intelligence Studies in Business, 3 (3), 54-62.

Kim, L. (1998). Crisis construction and organizational learning: Capability building in catching-up at Hyundai Motor. Organization Science, 9(4), 506-521.

Lane, P., Koka, B., \& Pathak, S. (2006). The reification of absorptive capacity: A critical review and rejuvenation of the construct. Academy of Management Review, 31 (4), 833-863.

Lane, P. J., \& Lubatkin, M. (1998). Relative absorptive capacity and interorganizational learning. Strategic Management Journal, 19(5), 461-477.

LaValle, S., Lesser, E., Shockley, R., Hopkins, M., \& Kruschwitz, N. (2011). Big data, analytics and the path from insights to value. MIT Sloan Management Review, 52(2), 21-32.

Liao, J., Welsch, H., \& Stoica, M. (2003). Organizational absorptive capacity and responsiveness: An empirical investigation of growth-oriented SMEs. Entrepreneurship Theory and Practice, 28(1), 63-86.

Matusik, S. F., \& Heeley, M. B. (2005). Absorptive capacity in the software industry: Identifying dimensions that affect knowledge and knowledge creation activities. Journal of Management, 31, 549-572.

McCracken, G. (1988). The long interview. Newbury Park, CA: Sage.

Miles, M., \& Huberman, A. (1990). Qualitative Data Analysis. London: Sage.

Nelson, R. R., \& Winter, S. G. (1982). An evolutionary theory of economic change. London: Harvard University Press.

Nemanich, L. A., Keller, R. T., Vera, D., \& Chin, W. W. (2010). Absorptive capacity in R\&D project teams: A conceptualization and empirical test. IEEE Transactions on Engineering Management, 57(4), 674-688.

Parker, L. D., \& Roffey, B. H. (1996). Methodological themes: Back to the drawing board: Revisiting grounded theory and the everyday accountant's 
and manager's reality. Accounting, Auditing \& Accountability Journal, 10(2), 212-247.

Petrini, M., \& Pozzebon, M. (2009). Usando Grounded Theory na construção de modelos teóricos. Revista Gestão e Planejamento, 10(1), 1-18.

Rodriguez, L., \& Cunha, C. (2018). Impacts of Big Data Analytics and absorptive capacity on sustainable supply chain innovation: A conceptual framework. Scientific Journal of Logistics, 14(2), 151-161.

Sáez, C. B., Arribas, E. H., \& García, T. (2002). Collaboration in R\&D with universities and research centers: An empirical study of Spanish firms. RED Management, 32 (4), 321-341.

Seidman, I. (2006). Interviewing as qualitative research: A guide for researchers in education and the social sciences (3rd ed.). New York: Teachers College Press.

Strauss, A. (1987). Qualitative analysis for social scientists. Cambridge, UK: CU Press.

Strauss, A., \& Corbin, J. (1998). Basics of qualitative reseach: Techniques and procedures for developing grounded theory (2nd ed.). Thousand Oaks: Sage.

Strauss, A., \& Corbin, J. (2008). Basics of qualitative research: Techniques and procedures for developing grounded theory (3rd ed.). Newbury Park, CA: Sage.

Szulanski, G. (1996). Exploring stickiness: Impediments to the transfer of best practice within the firm. Strategic Management Journal, 17, 27-43.

Tan, K. H., Zhan, Y., Ji, G., Ye, F., \& Chang, C. (2015). Harvesting big data to enhance supply chain innovation capabilities: An analytic infrastructure based on deduction graph. International Journal of Production Economics, 165, 223-233.

Todorova, G., \& Durisin, B. (2007). Absorptive capacity: Valuing a reconceptualization. Academy of Management Review, 32(3), 774-786.

Van den Bosch, F. J., \& Volberda, H. W. (August 2003). Absorptive capacity: Antecedents, models and outcomes. ERIM Report Series Research in Management ERS-2003-035-STR, 1-54.

Van den Bosch, F. J., Volberda, H. W, \& Boer, M. (1999). Coevolution of firm absorptive capacity and knowledge environment: Organizational forms and combinative capabilities. Organization Science, 10, 551-568.

Verma, S. (2017). Big Data and advance analytics: Architecture, techniques, applications, and challenges. International Journal of Business Analytics, 4(4), 21-47. 
Viaene, S., \& Bunder, A. van den (2011). The secrets to managing business analytics projects. MIT Sloan Management Review, 53(1), 65-69.

Volberda, H. W., \& Van Bruggen, G. H. (1997). Environmental turbulence: A look into its dimensionality. In M. T. A. Bemelmans (Ed.). Dynamiek in Bedrijfsvoering. Enschede, The Netherlands: NOBO.

Walsh, J. P., \& Ugson, G. R. (1991). Organizational memory. Academy of Management Review, 16, 57-91.

Wang, Y. (2015). Business intelligence and analytics education: Hermeneutic literature review and future directions in IS Education. Americas Conference on Information Systems, Puerto Rico, 21.

Wang, Y., Kung, L. A., \& Byrd, T. A. (2015). Big data analytics: Understanding its capabilities and potential benefits for healthcare organizations. Technological Forecasting and Social Change, 126, 3-13. doi:10.1016/j.techfore.2015.12.019

Zahra, S., \& George, G. (2002). Absorptive capacity: A review, reconceptualization and extension. Academy of Management Review, 27(2), 185-203.

\section{$\int$ AUTHOR NOTES}

Rodrigo Ferreira, doctor by the Post Graduate Program in Administration, University of Grande Rio (Unigranrio); Josir S. Gomes, doctor by the Institute for Graduate Studies and Research in Administration (Coppead), Federal University of Rio de Janeiro (UFRJ); Ana Carvalho, doctor by the School of Economics and Management (EEG), University of Minho (UM).

Rodrigo Ferreira is now cost manager at the social security technology and information company (Dataprev) and tutor teacher at the consortium of Public Universities of the State of Rio de Janeiro (Cederj); Josir S. Gomes is now adjunct professor at the Graduate Program in Administration of University of Grande Rio (Unigranrio); Ana Carvalho is now assistant professor at the School of Economics and Management (EEG) of University of Minho (UM).

Correspondence concerning this article should be addressed to Rodrigo Ferreira, Rua da Lapa, 86, $9^{\circ}$ andar, Lapa, Rio de Janeiro, RJ, Brazil, CEP 20021-180.

E-mail: rodrigoferreira.adm@bol.com.br

EDITORIAL BOARD

Editors-in-chief

Janette Brunstein

Silvia Marcia Russi De Domênico

Associated Editor

Carlos Ricardo Rossetto

Technical Support

Vitória Batista Santos Silva

\section{EDITORIAL PRODUCTION}

Publishing Coordination

Jéssica Dametta

Editorial Intern

Paula Di Sessa Vavlis

Language Editor

Daniel de Almeida Leão
Layout Designer

Emap

Graphic Designer

Libro 